\title{
Androgen-related expression of G-proteins in ovarian cancer
}

\section{LA Sheach',3, EM Adeney',3, A Kucukmetin², SJ Wilkinson', AD Fisher², A Elattar², CN Robson' and RJ Edmondson ${ }^{*, 1,2}$}

'Northern Institute for Cancer Research, Newcastle University, Newcastle, UK; ${ }^{2}$ Northern Gynaecological Oncology Centre, Queen Elizabeth Hospital, Gateshead, UK

BACKGROUND: Epidemiological and in vitro data implicate androgens in the aetiology of ovarian cancer, but the mechanisms by which this is mediated are unclear. In this study, we wished to examine the effects of androgens on gene expression in ovarian cancer. METHODS: The expression of androgen receptor (AR) in OVCAR3 and OSEC2 cells was confirmed using immunoblotting and response to androgens was measured using flow cytometric assessment of S-phase fraction. The differential gene expression between androgen stimulated and unstimulated OVCAR3 ovarian cancer cells was examined with a cDNA microarray. The upregulation of a subset of these genes was then confirmed with reverse transcriptase PCR in both OVCAR3 and OSEC2, an ovarian epithelial cell line. Finally, the clinical significance of this upregulation was investigated by examining the expression of Rab25 and Rab35, two G-protein-related molecules in an ovarian cancer tissue microarray (TMA).

RESULTS: OVCAR3 and OSEC2 cells were shown to express the AR and showed an increase in S-phase fraction in response to androgen treatment. Treatment of OVCAR3 cells with androgen resulted in a significant upregulation of $|2|$ genes. These findings were confirmed for a subset of seven monomeric G-protein-related genes in both OVCAR3 and OSEC2 cells. After staining for Rab25 and Rab35, the majority of TMA sections examined showed expression for Rab25 (92\%) and Rab35 (95\%). The expression of Rab25 correlated with histological grade, and expression was higher in endometrioid (median histoscore 10.5) than serous (7.5) or mucinous (5.3) tumours. The expression of Rab25 correlated positively with AR expression supporting its role as an androgen responsive gene in ovarian cancer.

CONCLUSIONS: These results suggest that androgens can effect expression of the oncogenic GTPases in ovarian cancer. We propose that the androgen responsive Rab35 may have clinical importance as a biomarker of AR function.

British Journal of Cancer (2009) I 01, 498-503. doi:I0.1038/sj.bjc.6605I53 www.bjcancer.com

Published online 2I July 2009

(c) 2009 Cancer Research UK

Keywords: ovarian cancer; androgens; G-proteins; gene expression

There is a wealth of evidence to suggest that many epithelial ovarian cancers (EOC) are hormonally related (Lukanova and Kaaks, 2005). Epithelial ovarian cancer is thought to arise from the ovarian surface epithelium (OSE), a single layer of cells overlying the ovary, which is in close proximity to the hormone-producing cells of the ovary. Many cancers are proposed to arise from invaginations of the OSE, which follow ovulation and create inclusion cysts (Auersperg et al, 2001). The cells lining these cysts lack a tunica albuginea, and are therefore exposed to even higher levels of steroid hormones, including oestrogens, progesterones and androgens.

Epidemiological evidence suggesting that hyperandrogenic states are associated with the development of EOC (Schildkraut et al, 1996; Wang and Chang, 2004; Gaducci et al, 2005) has led to the development of the androgenic theory of ovarian cancer development (Risch, 1998). Androgens exert their effects through activation of the androgen receptor (AR), a type I nuclear hormone receptor, involved in gene transcription. The action of $A R$ is controlled by a series of coregulators (Gnanapragasam et al, 2000).

* Correspondence: Dr RJ Edmondson, Northern Institute for Cancer Research, Paul O'Gorman Building, Newcastle University, NE2 4HH, UK; E-mail: richard.edmondson@ncl.ac.uk

3 These authors contributed equally to this work

Received 22 January 2009; revised 21 May 2009; accepted 27 May 2009; published online 21 July 2009
We have previously shown that OSE cells express the AR and respond to androgen stimulation resulting in increased proliferation and protection from apoptosis (Edmondson et al, 2002), others have shown that the majority of ovarian cancers continue to express the AR (Kuhnel et al, 1987; Ilekis et al, 1997; Lee et al, 2005). Other phenotypic effects of androgens on ovarian cancer cells and how these are mediated are poorly understood, although it has been shown that androgen treatment allows these cells to escape the growth inhibitory effect of transforming growth factor $\beta$ $(\operatorname{TGF} \beta)$ by downregulating the expression of the TGF receptors, TGF $\beta$ R I and II (Evangelou et al, 2000). Androgen stimulation also results in changes in expression of the steroid hormone coregulators, SRC-1, ARA70 and AIB1, although this cofactor is lost in the neoplastic transformation of OSE cells to EOC (Evangelou et al, 2003).

Here, we investigate the effects of androgens on gene expression in cells expressing the AR, and investigate the clinical relevance of the subsequently identified androgen responsive genes.

\section{MATERIALS AND METHODS}

\section{Tissue microarray}

The Newcastle ovarian cancer tissue microarray (TMA) has been described previously (Wilkinson et al, 2008). Briefly, the TMA 
comprises 154 cases of histologically confirmed EOC, with accompanying clinical data available for each case. All tissue samples were taken from sequential patients who underwent primary surgery between 1995 and 2000 at the Northern Gynaecological Oncology Centre, Gateshead, UK, with appropriate ethical approval. All patients underwent maximal-effort primary cytoreductive surgery followed by platinum-based chemotherapy with or without paclitaxel.

\section{Cell lines and cell culture}

OVCAR3 cells were obtained from the American Tissue and Cell Collection and maintained in RPMI-1640 medium (Sigma-Aldrich, Poole, UK) with the addition of $20 \%(\mathrm{v} / \mathrm{v})$ foetal bovine serum (Sigma-Aldrich) and 1\% L-Glutamine (20 mM) (Sigma-Aldrich).

OSEC2 cells have been previously described (Davies et al, 2003). Briefly this cell line was derived from a primary culture of normal ovarian epithelial cells created following an oophorectomy for a non-malignant pathology. Cells were immortalised using hTERT and the temperature-sensitive form of SV40 large T antigen. OSEC2 cells are maintained at the permissive temperature of $30^{\circ} \mathrm{C}$ in RPMI-1640 medium (Sigma-Aldrich) with the addition of $10 \%$ foetal bovine serum (Sigma-Aldrich) and 1\% L-Glutamine (20 mM) (Sigma-Aldrich).

\section{Cell proliferation assays}

Cell cycle analysis was carried out using flow cytometry. After stimulation with dihydrotestosterone (DHT), cells were harvested, washed in PBS and resuspended in a propidium iodide (PI) solution (RNAase $(1 \% \mathrm{w} / \mathrm{v})$, PI $(18 \% \mathrm{w} / \mathrm{v})$, FCS $(2 \% \mathrm{v} / \mathrm{v})$ in $5 \%$ Triton) for $30 \mathrm{~min}$ before being analysed on a Becton-Dickinson FACScan Flow Cytometer (BD Becton-Dickinson UK Limited, Oxford, UK). Data were analysed using WinMidi software (Scripps Institute, San Diego, CA, USA).

Cell proliferation was measured using a sulphorhodamine $\mathrm{B}$ (SRB) assay. Briefly, cells were seeded in 96-well plates, washed with PBS and quiesced in serum-free medium for $48 \mathrm{~h}$ before DHT treatment. Cells were fixed with 50\% trichloroacetic acid and stained with $0.4 \%$ SRB solution before the addition of $10 \mathrm{~mm}$ Tris. All plates were analysed on a spectrophotometer at $570 \mathrm{~nm}$. Data presented are the results of six independent experiments.

\section{Western blotting}

Cells were harvested in lysis buffer ( $1 \%$ Triton-X, $0.1 \%$ sodium dodecyl sulphate, $0.5 \%$ sodium deoxycholate) and were fractionated using SDS-PAGE in a mini-protean III system (BioRad, Herts, UK) followed by electrotransfer onto nitrocellulose membrane (Hydrobond C, Amersham Biosciences, Amersham, UK).

Membranes were incubated overnight at $4{ }^{\circ} \mathrm{C}$ with mouse monoclonal anti-human $\mathrm{AR}$ antibody, at a concentration of 1:1000 (clone AR441, Dako, Glostrup, Denmark). Blots were reprobed with anti- $\alpha$-tubulin antibody $(1: 2000)$ (Dako) to confirm equal loading of protein.

The immunocomplex was detected using appropriate secondary antibodies and visualised using enhanced chemiluminescence detection system (ECL)(Amersham Biosciences).

\section{cDNA microarray analysis and real-time RT-PCR}

Total RNA was extracted from DHT stimulated and unstimulated OVCAR3 cells using a commercially available kit (RNeasy, Qiagen, Crawley, UK). Concentrations of RNA $>1000 \mathrm{ng}^{-1} \mathrm{l}^{-1}$ were used for cDNA microarray analysis (Human Genome U133 Plus 2.00 gene chip, Affymetrix, High Wycombe, UK). Data were normalised and analysed using Genespring software (Agilent Technologies, Edinburgh, UK). A twofold change in gene expression compared with unstimulated cells was considered significant. Ontological analysis was performed using the Netaffx database (http://Affymetrix. com/). Quantitative real-time RT-PCR analysis was performed using Jumpstart SYBR Green master mix (Sigma-Aldrich) and specific primers (VH Bio Ltd, Gateshead, UK) were designed using Primer Express software (version 2.0, Applied Biosystems Inc. Foster City, CA, USA). Expression levels were normalised against a housekeeping gene, GAPDH. All QPCR experiments were performed on a 7900-HT sequence detection system and integral SDS software (Applied Biosystems, Warrington, UK) was used for analysis.

\section{Immunohistochemistry}

Tissue microarray sections were deparaffinised and rehydrated through a series of graded alcohols. Antigen retrieval was achieved by the pressure cooker method in $0.01 \mathrm{M}$ citrate buffer ( $\mathrm{pH} 6.0$ ). Slides were then washed in PBS before being treated with a $1.7 \%$ hydrogen peroxide/methanol solution. A total of $10 \%$ blocking serum was applied for $20 \mathrm{~min}$ at room temperature before application of the primary antibody overnight at $4{ }^{\circ} \mathrm{C}$. Monoclonal mouse anti-human AR antibody was used at a concentration of 1:20 (clone 441, Santa Cruz, Heidelberg, Germany). Monoclonal mouse anti-human Rab25 antibody was used at a concentration of 1:500 (clone 3F12F3, ProMab Biotechnologies, Richmond, CA, USA). Polyclonal rabbit anti-human Rab35 antibody was used at a concentration of 1:20 (Proteintech, Manchester, Peterborough, UK). Primary antibody was detected with an appropriate biotin-conjugated secondary antibody (Vector Laboratories, Peterborough, UK). Slides were then developed using an avidin-biotin-peroxidase complex kit (Vectastain, Vector Laboratories), incubated with $3^{\prime}, 3^{\prime}$ diaminobenzidine (Sigma-Aldrich), counterstained using Harris' haematoxylin before being dehydrated and mounted. Negative control sections were incubated with secondary antibody alone. Tissue controls included prostate, breast and thyroid tissues for AR, Rab25 and Rab35, respectively. Each core was independently scored by two of the authors (EMA and RJE) using a modified $H$-score (Leake $e t a l, 2000)$. The $H$-score is a multiplicative score generated by two parameters, namely maximal intensity of staining and percentage area of the section stained. Scores range from 0 (no staining throughout the section) to 18 (high intensity staining throughout the whole section). Any differences of opinion were mutually resolved, For the purpose of analysis, scores were further categorised as low (less than median score) or high (greater than median score).

\section{Statistics}

Statistical analysis was performed using SPSS version 11.0 (SPSS Inc., Chicago, IL, USA). Statistical significance was evaluated using the log-rank test, non-parametric analysis by Kruskal-Wallis, Kaplan-Meier analysis for survival and Cox regression for multivariate analysis. A $P$-value of $<0.05$ was considered statistically significant. Correlation was analysed using Spearman's correlation.

\section{RESULTS}

OVCAR 3 and OSEC2 cells express AR and are responsive to androgen stimulation

The presence of AR in OVCAR3 and OSEC2 cells was confirmed using western blot of nuclear and cytoplasmic extracts after DHT treatment. Androgen receptor protein was found to be exclusively nuclear, in keeping with a functional protein (Figure 1).

Stimulation of OSEC2 and OVCAR3 cells with increasing doses of DHT for $24 \mathrm{~h}$ resulted in an increase in cell proliferation of up to $25 \%$ over unstimulated cells (Figure 2A). This observed increase was abrogated with the addition of the AR-specific antagonist, Casodex, suggesting that this effect is AR dependent (Figure 2B). Stimulation of OVCAR3 cells with increasing doses of DHT for $24 \mathrm{~h}$ results in an increase in the S-phase fraction over unstimulated cells (Figure 2C). 
Androgen stimulation promotes differential expression of multiple genes

Messenger RNA was extracted from OVCAR3 cells that were either untreated or exposed to $10 \mathrm{~nm}$ of DHT for 2 or $8 \mathrm{~h}$. Microarray analysis was then performed using the Affymetrix u133 gene chips

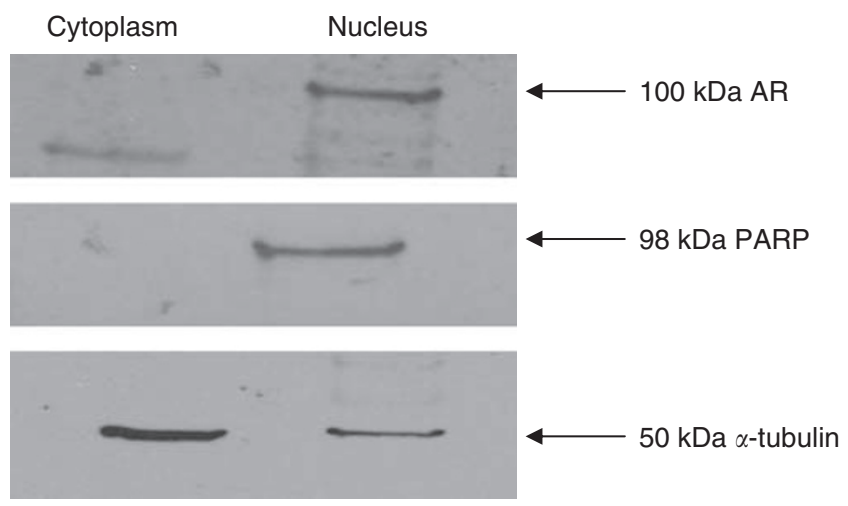

Figure I Western blot showing nuclear and cytoplasmic fractions of OVCAR3 cells after treatment with $10 \mathrm{nM}$ DHT. Androgen receptor (AR) is expressed in the nuclear fraction, as confirmed by the presence of PARP, in contrast to the cytoplasmic fraction suggesting the presence of functionally active protein.
(Affymetrix) and the expression was compared with that of nonstimulated cells. Results were normalised and analysed using Genespring software. Stimulation with DHT resulted in greater than twofold upregulation of 33 and 105 genes at 2 and $8 \mathrm{~h}$, respectively, and downregulation of 1 and 16 genes at 2 and $8 \mathrm{~h}$, respectively. Seven genes were upregulated at both 2 - and 8-h time points.

Ontological analysis of the upregulated genes indicated that the majority were related to gene transcription, but some genes associated with proliferation and G-protein signalling were also found to be increased compared with the untreated controls (Table 1).

Table I Ontological classification of genes upregulated in OVCAR3 cells after exposure to $10 \mathrm{nM}$ DHT

\begin{tabular}{lcccc}
\hline Ontological group & $\mathbf{2}$ h & $\mathbf{8 h}$ & Both & Total \\
\hline Transcription & 19 & 47 & 3 & 63 \\
Proliferation & 7 & 14 & 1 & 20 \\
G-protein signalling & 3 & 12 & 2 & 13 \\
Apoptosis & 1 & 17 & 0 & 18 \\
Ubiquitination & 1 & 7 & 1 & 7 \\
Cell adhesion & 2 & 8 & 0 & 10 \\
Total & 33 & 105 & & 131 \\
\hline
\end{tabular}

$\mathrm{DHT}=$ dihydrotestosterone.
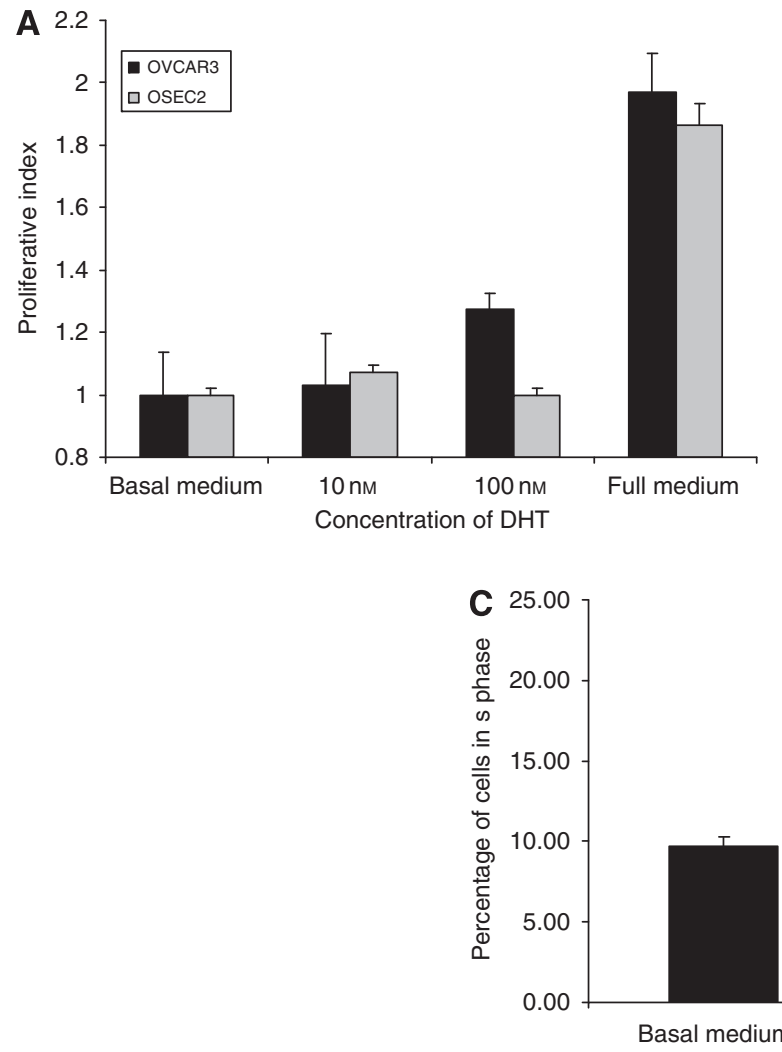
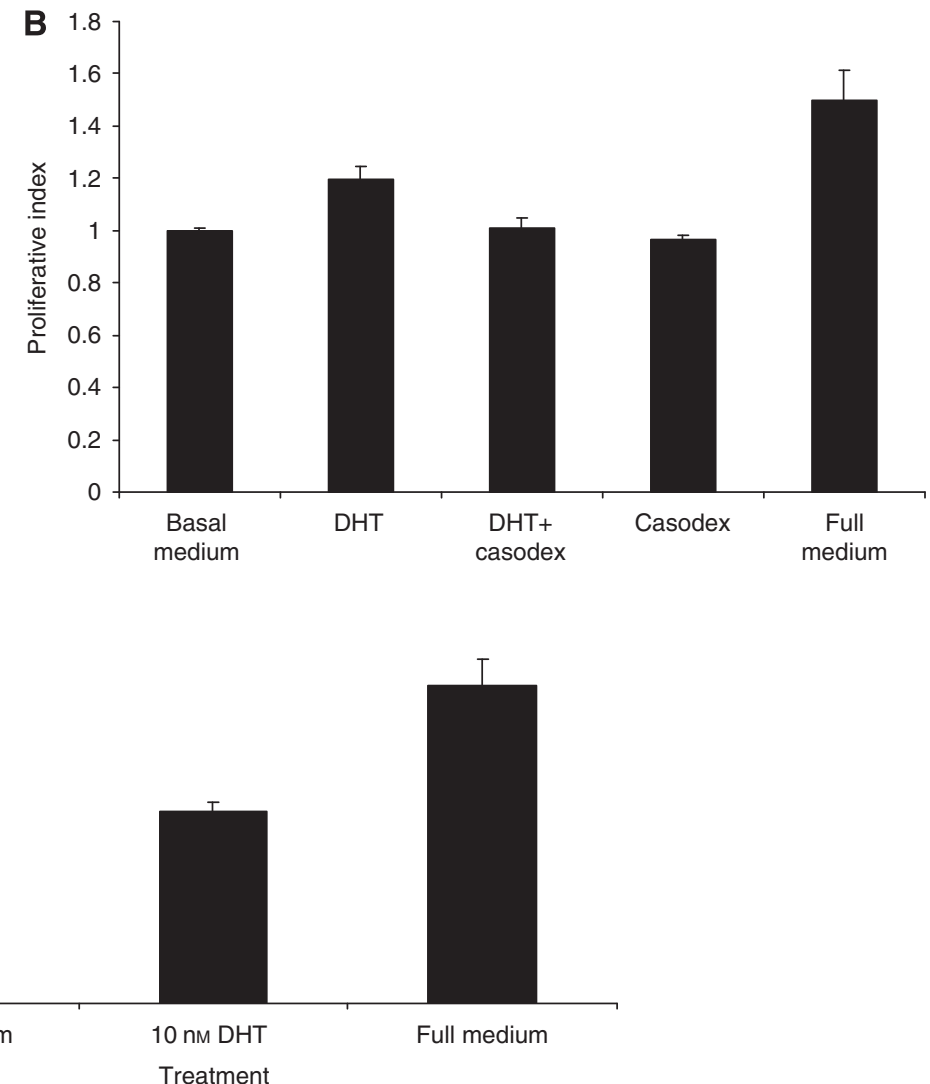

Figure 2 Treatment with DHT results in an increase in cell proliferation in both normal and malignant ovarian cells. (A) OSEC2 and OVCAR 3 cells were stimulated for $24 \mathrm{~h}$ with DHT before analysis using an SRB assay. Both cell lines show increases in cell proliferation after DHT stimulation of up to $24 \mathrm{~h}$. Increased cell proliferation is shown using a dose of I $0 \mathrm{nM}$ in the OSEC2 cells, but a dose of $100 \mathrm{nM}$ in OVCAR3 cells. (B) OVCAR3 cells were treated for $24 \mathrm{~h}$ with $10 \mathrm{nM}$ DHT in the presence and absence of the specific AR inhibitor, Casodex, before analysis using an SRB assay. The androgen-induced stimulation is abrogated by the addition of Casodex. Casodex alone had no effect on cell proliferation. (C) OVCAR3 cells were treated with DHT for $24 \mathrm{~h}$ and the S-phase fraction analysed using propidium iodide incorporation. Cells stimulated with DHT show a dose-dependent increase in the S-phase fraction compared with non-treated cells. 
Table 2 Changes in expression of G-proteins after 8-h stimulation by $10 \mathrm{nM}$ DHT

\begin{tabular}{|c|c|c|c|c|c|}
\hline Gene & Accession number & Brief description of known function & \multicolumn{3}{|c|}{ Maximal fold change upregulation } \\
\hline GNA 13 & NM_006572 & $\alpha$-Subunit of heterotrimeric G-protein 13 & 2.2 & 5.5 & |46.| \\
\hline ELKS & $\mathrm{AB} 029004$ & RAB6-interacting protein 2. Regulator of NF- $\kappa$ B signalling & 2.9 & 2 & 1.4 \\
\hline GSTP I & BE544748 & G to S-phase transition protein I & 2.5 & 2 & 7.8 \\
\hline Rab45 & NM_I52573 & Monomeric G-protein. Involved in vesicle trafficking & 2.5 & 2.5 & 8.6 \\
\hline Rab35 & NM_00686I & Monomeric G-protein. Involved in vesicle trafficking & 5.4 & 13 & |3.1 \\
\hline
\end{tabular}

$\mathrm{DHT}=$ dihydrotestosterone; NF- $\kappa \mathrm{B}=$ nuclear factor $\kappa \mathrm{B} ; \mathrm{RT}-\mathrm{PCR}=$ reverse transcriptase $\mathrm{PCR}$
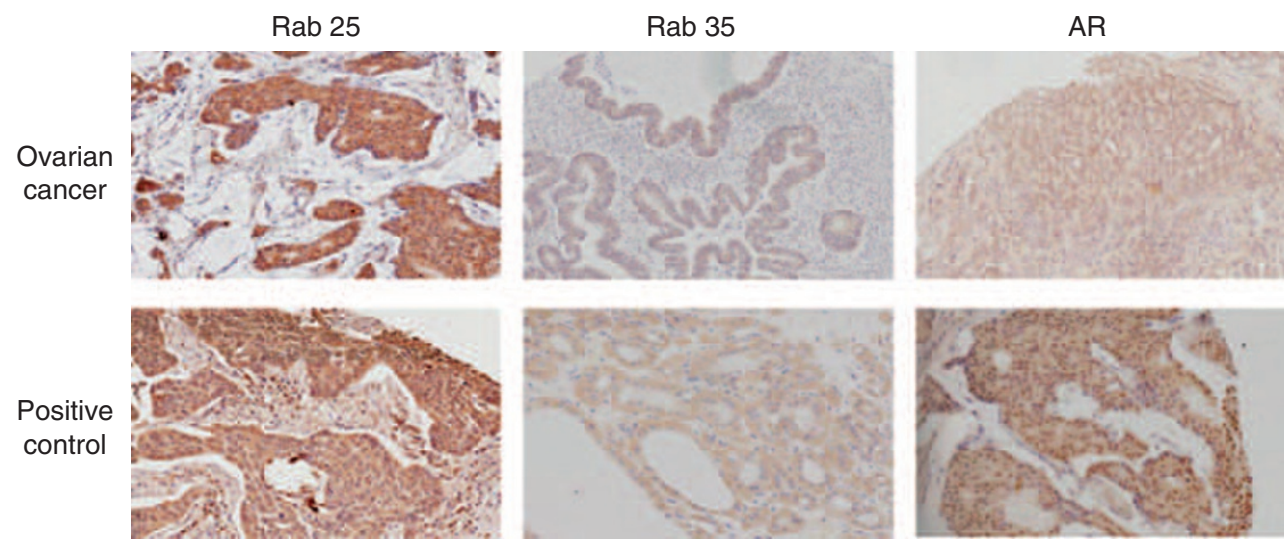

Figure 3 Rab25, Rab35 and AR expression in clinical samples. Rab25, Rab35 and AR protein expression levels were determined using immunohistochemical techniques for 154 epithelial cancer samples arrayed on a TMA. Representative sections are shown demonstrating predominantly cytoplasmic staining for Rab25 and Rab35, and nuclear staining for AR. Breast, thyroid and prostate sections were used as positive controls for Rab25, Rab35 and $A R$, respectively.

Upregulation of mRNA expression was confirmed in a subset of eight G-protein-related genes using RT-PCR. Changes in mRNA levels of G-protein-related genes in both OVCAR3 and OSEC2 cells after stimulation with $10 \mathrm{nM}$ of DHT for $2,4,8$, and $12 \mathrm{~h}$ confirmed the data obtained from the microarray experiment for the subset of genes tested (Table 2).

\section{Rab25, Rab35 and AR are expressed by ovarian cancers}

In light of the finding that G-proteins were upregulated in response to androgen stimulation, we decided to further investigate the expression of two of these proteins in clinical ovarian cancer samples. Rab35 was chosen as it was the most highly upregulated gene in the cDNA microarray experiment, and Rab25 was chosen as this protein has been linked with ovarian cancer (Cheng et al, 2004a, b; Cheng et al, 2005).

Clinical characteristics of the patient samples included in the TMA have been previously published (Wilkinson et al, 2008). The TMA was stained for AR expression (Figure 3). As expected, staining was predominantly nuclear, $86 \%$ of samples showed positivity for AR. Androgen receptor scores showed no correlation with FIGO stage, histological subtype, residual disease, preoperative CA125 levels or overall survival.

The TMA was then stained for Rab25 expression (Figure 3). The majority of staining was cytoplasmic, with $92 \%$ of samples showing positivity for Rab25. Rab25 scores were higher in endometrioid tumours (median score 10.5) compared with serous (median score 7.5), mucinous (median score 5.3) and clear cell (median score 5.8) tumours, but there was no correlation with FIGO stage or residual disease (Table 3). Overall, Rab25 expression did not correlate with survival, but when classified by histological subtype, high expressors (expression greater than the median score (7.5)) showed variation by histological subtype unlike low expressors, which showed no variation in survival (Figure 4).

The TMA was stained for Rab35 expression (Figure 3). As expected, staining was entirely cytoplasmic, $95 \%$ of samples showed positivity for Rab35. Rab35 scores showed no correlation with FIGO stage, histological subtype, residual disease, preoperative CA125 levels or overall survival when analysed by high and low expressors (high expressors defined as expression greater than the median score (4.7)).

Finally, correlation was investigated between scores for $A R$, Rab25 and Rab35 expression. No significant correlation was found between Rab25 and AR expression, but a significant positive correlation was seen between Rab35 and AR expression, $(r=0.23$, $P<0.01)$.

\section{DISCUSSION}

We have described here the effects of the androgen DHT on both cell proliferation and gene expression in ovarian cancer cells. This physiologically important hormone has been linked with ovarian cancer; however, this is the first study investigating the effects of acute exposure to androgens on gene expression. The findings are therefore likely to differ from other studies in which gene 
expression was analysed after chronic exposure to androgens (Motamed-Khorasani et al, 2007).

We have shown that, in addition to some predicted increases in gene expression in genes encoding proteins related to transcription regulation and cell cycle control, there was also an increase in the expression of several proteins related to G-protein signalling. The G-proteins are a superfamily of ubiquitous signalling molecules. They are involved in intracellular signalling from G-proteincoupled receptors (GPCR), other receptors and also independently (Andreeva et al, 2007). There are two distinct groups of G-proteins: the large (heterotrimeric) form, and the small (monomeric) form, otherwise known as the Ras superfamily of GTPases. The large

Table 3 Correlation of expression of Rab25 and Rab35 with clinical parameters

\begin{tabular}{|c|c|c|c|c|c|c|c|}
\hline \multirow[b]{2}{*}{ Variable } & \multirow[b]{2}{*}{ n (\%) } & \multicolumn{2}{|c|}{ Rab25 } & \multicolumn{2}{|c|}{ Rab35 } & \multicolumn{2}{|l|}{ AR } \\
\hline & & Median & $P$ & Median & $P$ & Median & $P$ \\
\hline Available to score & 154 & & & & & & \\
\hline $\begin{array}{l}\text { Stage } \\
\text { I } \\
\text { II } \\
\text { III } \\
\text { IV } \\
\text { Missing }\end{array}$ & $\begin{array}{l}27(17.5) \\
14(9) \\
91(59) \\
18(12) \\
4(3)\end{array}$ & $\begin{array}{c}7 \\
11.3 \\
7.5 \\
7.8\end{array}$ & 0.78 & $\begin{array}{l}4.7 \\
4.5 \\
4.7 \\
5.7\end{array}$ & 0.76 & $\begin{array}{c}7.25 \\
11.25 \\
7.5 \\
8.25\end{array}$ & 0.6 \\
\hline $\begin{array}{l}\text { Grade } \\
\qquad \begin{array}{l}1 \\
2 \\
3 \\
\text { Missing }\end{array}\end{array}$ & $\begin{array}{c}38(25) \\
41(27) \\
75(49) \\
0\end{array}$ & $\begin{array}{l}7 \\
7.8 \\
7.5\end{array}$ & 0.49 & $\begin{array}{l}5.5 \\
4 \\
4.7\end{array}$ & 0.58 & $\begin{array}{l}7.5 \\
8.5 \\
7.5\end{array}$ & 0.75 \\
\hline $\begin{array}{l}\text { Histological subtypes } \\
\text { Serous } \\
\text { Mucinous } \\
\text { Endometrioid } \\
\text { Clear cell } \\
\text { Missing }\end{array}$ & $\begin{array}{l}73(47) \\
16(10) \\
47(31) \\
15(10) \\
3(2)\end{array}$ & $\begin{array}{r}7.5 \\
5.3 \\
10.3 \\
5.8\end{array}$ & 0.001 & $\begin{array}{l}5 \\
3.7 \\
5.3 \\
6.1\end{array}$ & 0.32 & $\begin{array}{c}7.5 \\
5.25 \\
10.5 \\
6\end{array}$ & 0.02 \\
\hline $\begin{array}{l}\text { Residual disease } \\
\text { None } \\
\leqslant 1 \mathrm{~cm} \\
>1 \mathrm{~cm} \\
\text { Missing }\end{array}$ & $\begin{array}{c}54(35) \\
30(19) \\
64(42) \\
6(4)\end{array}$ & $\begin{array}{l}8.5 \\
8.5 \\
7\end{array}$ & 0.56 & $\begin{array}{l}4.7 \\
4.8 \\
5\end{array}$ & 0.32 & $\begin{array}{l}9 \\
8.5 \\
7\end{array}$ & 0.4 \\
\hline
\end{tabular}

$\mathrm{AR}=$ androgen receptor.
G-proteins exist at the cell surface next to the GPCR and are made up of three sub units: $\alpha, \beta$ and $\gamma$. Ligand binding and exchange of GDP for GTP on the $\alpha$-subunit allow signal transduction, which is terminated by GTP hydrolysis back to GDP. The small GTPases exist unbound to the GPCR. They contain an $\alpha$-subunit with a structurally homologous GTPase domain to that of the large heterotrimeric G-proteins (Oldham and Hamm, 2006). Similarly, their action depends upon the binding of GTP. Once activated, they initiate signalling cascades, phosphorylating downstream proteins and causing an effect. They are split further into five families: Ras, Rho, Rab, Ran and Arf. We have shown that when stimulated with androgens, a number of G-proteins are upregulated in OVCAR3 cells. We investigated two of the small G-proteins further: Rab25 and Rab35. We chose to examine Rab35 as this was the most differentially expressed gene upon androgen stimulation, and Rab25 as a comparison as this was only marginally altered in response to androgens.

Rab25 is a small GTPase of $28 \mathrm{kDa}$, localised in epithelial cells. It is involved in protein trafficking from the cell membrane to cytoplasmic vesicles (Cheng et al, 2005), and is known to be involved in proliferation, protection from apoptosis and invasion in ovarian cancers (Yang et al, 2006). It has been shown to be upregulated in $80 \%$ of ovarian cancers and its expression correlates with a worse disease-free survival in both ovarian and breast cancers (Cheng et al, 2004a, b).

Of interest is the observation that Rab25 expression is only marginally upregulated after exposure to androgen, as an androgen response element in the antisense strand of the Rab25 gene has been found (Louro et al, 2007). It is possible that effects observed on Rab25 expression are mediated by an indirect mechanism, perhaps through TGF $\beta$ receptors, which have been shown to interact with the AR in ovarian cancer (Evangelou et al, 2000). Furthermore, it has been proposed that endometrioid tumours develop as a result of TGF $\beta$ R-II (Lynch et al, 1998) and MSH2 (Fujita et al, 1995) mutations rather than mutations of $\mathrm{k}$-Ras (Enomoto et al, 1991). Our finding, therefore, that Rab25 expression is greatest in endometrioid tumours does not rule out a possible indirect interaction between androgen stimulation, the $\mathrm{TGF} \beta$ receptors and $\mathrm{Rab} 25$.

Another small GTPase, Rab35, was the most upregulated upon androgen stimulation in our experiments. Little is known about this protein, although it is thought to be involved in endocytic recycling (Kouranti et al, 2006) and may play a role in the modulation of $\mathrm{p} 53$ by regulating the p53-related protein kinase, PRPK, giving it oncogenic potential (Abe et al, 2006). We have not shown any clinical significance related to Rab35 expression, although $95 \%$ of the tumours examined showed expression of
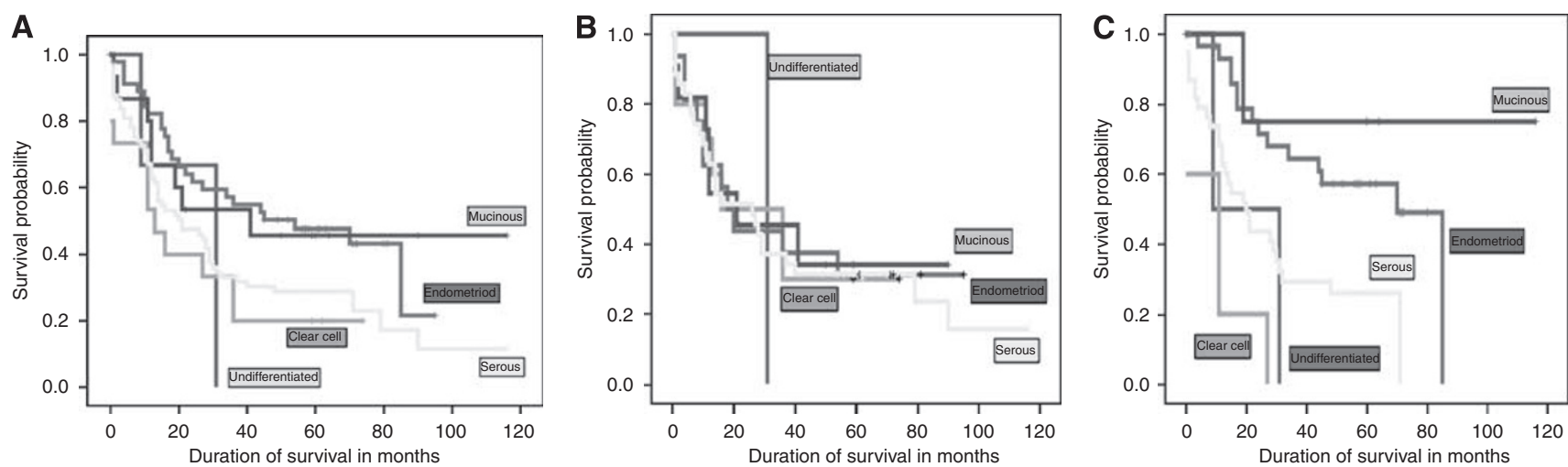

Figure 4 High expression of Rab25 predicts survival by histological type. (A) Kaplan-Meier survival curves of all patients included in this study show differential expression by histological type. (B) Kaplan-Meier curves of only those tumours showing low expression of Rab25 shows no difference in survival (C) Kaplan-Meier curves of only those tumours showing high expression of Rab25 attenuates this finding with improved survival in mucinous and endometrioid tumours compared with serous and clear cell cancers $(P=0.043)$. 
the protein. The finding that Rab35 and AR expression correlate supports the concept that Rab35 is an androgen responsive gene, and given the timescale of upregulation after androgen stimulation, it is likely that this is a direct effect. Further work is required to investigate the functional role of Rab35 in ovarian cancer, but this gene may have use as a biomarker of AR function in ovarian cancer, thus being able to predict those patients who are likely to respond to antiandrogen therapy.

Taken together, these data suggest that androgen treatment has downstream effects on small G-protein signalling cascades, however, this effect only occurs in a subset of ovarian cancers. Further work is required to investigate these effects, and to identify whether there is a subset of ovarian cancers in which this is important, which may be suitable for a targeted antiandrogen therapy.

\section{ACKNOWLEDGEMENTS}

LAS and EMA were funded by the Northern Cancer Care and Research Society. We also thank Dr D Swan for his help with analysis of the cDNA microarray data. This study was funded by the Northern Cancer Care and Research Society.

\section{Conflict of interest}

The authors declare no conflict of interest.

\section{REFERENCES}

Abe Y, Takeuchi T, Imai Y, Murase R, Kamei Y, Fujibuchi T, Matsumoto S, Ueda N, Ogasawara M, Shigemoto K, Kito K (2006) A small Ras-like protein Ray/Rab1c modulates the p53-regulating activity of PRPK. Biochem Biophys Res Commun 344(1): 377-385

Andreeva A, Kutuzov M, Voyno-Yasenetskaya T (2007) Scaffolding proteins in G-protein signaling. J Mol Signal 2(1): 13

Auersperg N, Wong A, Choi K, Kang S, Leung P (2001) Ovarian surface epithelium: biology, endocrinology, and pathology. Endocrine rev 22: $255-288$

Cheng KW, Lahad J, Kuo W, Lapuk A, Yamada K, Auersperg N, Liu J, Smith-McCune K, Lu K, Fishman D, Gray J, Mills G (2004a) The RAB25 small GTPase determines aggressiveness of ovarian and breast cancers. Nat Med 10: $11251-11256$

Cheng KW, Lahad JP, Gray JW, Mills GB (2005) Emerging role of RAB GTPases in cancer and human disease. Cancer Res 65(7): 2516-2519.

Cheng KW, Lahad JP, Kuo W-l, Lapuk A, Yamada K, Auersperg N, Liu J, Smith-McCune K, Lu KH, Fishman D, Gray JW, Mills GB (2004b) The RAB25 small GTPase determines aggressiveness of ovarian and breast cancers. Nat Med 10(11): 1251-1256

Davies BR, Steele IA, Edmondson RJ, Zwolinski SA, Saretzki G, von Zglinicki T, O'Hare MJ (2003) Immortalisation of human ovarian surface epithelium with telomerase and temperature-sensitive SV40 large $\mathrm{T}$ antigen. Exp Cell Res 288(2): $390-402$

Edmondson R, Monaghan J, Davies B (2002) The human ovarian surface epithelium is an androgen responsive tissue. $\mathrm{Br} J$ Cancer 86: $879-885$

Enomoto T, Weghorst C, Inoue M, Tanizawa O, Rice J (1991) K-ras activation occurs frequently in mucinous adenocarcinomas and rarely in other common epithelial tumors of the human ovary. Am J Pathol 139(4): $777-785$

Evangelou A, Jindal SK, Brown TJ, Letarte M (2000) Down-regulation of transforming growth factor \{beta\} receptors by androgen in ovarian cancer cells. Cancer Res 60(4): 929-935

Evangelou A, Letarte M, Jurisica I, Sultan M, Murphy KJ, Rosen B, Brown TJ (2003) Loss of coordinated androgen regulation in nonmalignant ovarian epithelial cells with brca1/2 mutations and ovarian cancer cells. Cancer Res 63(10): 2416-2424

Gaducci A, Gargini A, Palla E, Fanucchi A, Genazzani AR (2005) Polycystic ovary syndrome and gynecological cancers: is there a link? Gynecol Endocrinol 20(4): $200-208$

Gnanapragasam V, Robson C, Leung H, Neal D (2000) Androgen receptor signalling in the prostate. BJU Int 86: $1001-1013$

Ilekis J, Connor J, Prins G, Ferrer K, Niederberger C, Scoccia B (1997) Expression of epidermal growth factor and androgen receptors in ovarian cancer. Gynecol Oncol 66(2): 250-254
Kouranti I, Sachse M, Arouche N, Goud B, Echard A (2006) Rab35 regulates an endocytic recycling pathway essential for the terminal steps of cytokinesis. Curr Biol 16(17): 1719-1725

Kuhnel R, de Graaff J, Rao B, Stolk J (1987) Androgen receptor predominance in human ovarian carcinoma. J Steroid Biochem 26: 393-397

Leake R, Barnes D, Pinder S, Ellis I, Anderson L, Anderson T, Adamson R, Rhodes T, Miller K, Walker R (2000) Immunohistochemical detection of steroid receptors in breast cancer: a working protocol. J Clin Pathol 53(8): 634-635.

Lee P, Rosen D, Zhu C, Silva E, Liu J (2005) Expression of progesterone receptor is a favorable prognostic marker in ovarian cancer. Gynecol Oncol 96(3): 671-677

Louro R, Nakaya H, Amaral P, Festa F, Sogayar M, da Silva A, VerjovskiAlmeida S, Reis E (2007) Androgen responsive intronic non-coding RNAs. BMC Biol 5: 4

Lukanova A, Kaaks R (2005) Endogenous hormones and ovarian cancer: epidemiology and current hypotheses. Cancer Epidemiol Biomarkers Prev 14(1): $98-107$

Lynch MA, Nakashima R, Song H, DeGroff VL, Wang D, Enomoto T, Weghorst CM (1998) Mutational analysis of the transforming growth factor $\{$ beta\} receptor type. Cancer Res 58(19): 4227-4232

Fujita M, Enomoto T, Yoshino K, Nomura T, Buzard GS, Inoue M, Okudaira Y (1995) Microsatellite instability and alterations in the HMSH2 gene in human ovarian cancer. Int J Cancer 64(6): 361-366

Motamed-Khorasani A, Jurisica I, Letarte M, Shaw P, Parkes R, Zhang X, Evangelou A, Rosen B, Brown T (2007) Differentially androgenmodulated genes in ovarian epithelial cells from BRCA mutation carriers and control patients predict ovarian cancer survival and disease progression. Oncogene 26: 198-214

Oldham W, Hamm H (2006) Structural basis of function in heterotrimeric G-proteins. Q Rev Biophys 39: 117

Risch H (1998) Hormonal etiology of epithelial ovarian cancer, with a hypothesis concerning the role of androgens and progesterone. $J$ Natl Cancer Inst 90(23): 1774-1786

Schildkraut JM, Schwingl PJ, Bastos E, Evanoff A, Hughes C (1996) Epithelial ovarian cancer risk among women with polycystic ovary syndrome. Obstetrics Gynecol 88(4 I): $554-559$

Wang PH, Chang C (2004) Androgens and ovarian cancers. Eur J Gynecol Oncol 25: $157-163$

Wilkinson SJ, Kucukmetin A, Cross P, Darby S, Gnanapragasam VJ, Calvert AH, Robson CN, Edmondson RJ (2008) Expression of gonadotrophin releasing hormone receptor $\mathrm{I}$ is a favorable prognostic factor in epithelial ovarian cancer. Hum Pathol 39(8): $1197-1204$

Yang F, Xiao-Yan X, Bi-Liang C, Xiang Dong M (2006) Knockdown of Rab25 expression by RNAi inhibits growth of human epithelial ovarian cancer cells in vitro and in vivo. Pathology 38(6): $561-567$ 